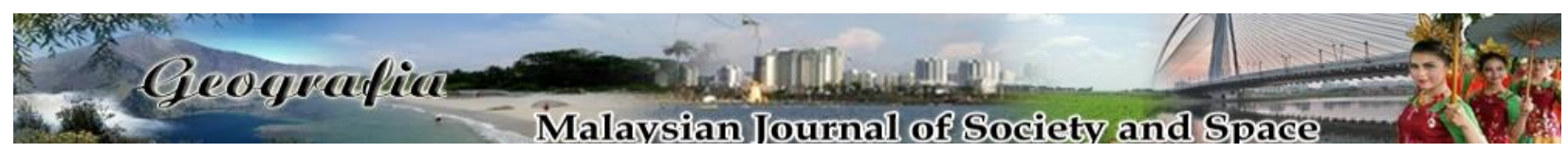

\title{
Small Medium Enterprises (SMEs) business owner's wellbeing and business growth in Malaysia.
}

\author{
Engku Aiesyah Amirah Engku Md Azmi
}

Fakulti Reka Bentuk Inovatif dan Teknologi, Universiti Sultan Zainal Abidin, Terengganu

Correspondence: Engku Aiesyah Amirah Engku Md Azmi (email: aiesyahamirah@unisza.edu.my)

Received: 01 October 2020; Accepted: 24 November 2020; Published: 29 November 2020

\begin{abstract}
The most common attribute found among successful Small Medium Enterprises (SMEs) is constantly growing their business. Business owner's wellbeing evidently played pivotal role in SMEs business growth. Although extensive research has been carried out on the subject of SMEs business growth, their wellbeing remained relatively under-explored. As a result, a thorough understanding on SMEs business owner's wellbeing in Terengganu was very poor and the barriers to business growth remain persistent. It is against this backdrop that this paper seeks to explore SMEs business owner's attitude which impede their business growth that directly linked with their wellbeing. Analysis of data from 30 semi-structured interviews with SMEs related experts and business owners revealed six common traits of business owners' attitude; complacent, reliance, expectation, inculpate, unmotivated and incurious. In addition to common traits, findings revealed further understanding on their attitudinal motivations. Thorough understanding on SMEs business owner's attitude found among participants in this study explained their minimal growth which lies beyond superficial negative attribute that was projected, rather, driven by external circumstances. This study provides a fine-grained understanding of SMEs business owner's wellbeing in Terengganu through a lenses of both experts and business owners.
\end{abstract}

Keywords: business growth, business owners, small medium enterprises (SMEs), wellbeing.

\section{Introduction}

Small and Medium Enterprises (SMEs) are a fundamental property and a driven factor of economy for the country. In Malaysia, SMEs account for $98.5 \%$ which is the largest proportions of businesses and contributes $37.1 \%$ to the country's GDP and $66 \%$ of employment (SME Corporation Malaysia, 2018). Therefore a positive business growth as well as long-term longevity of the business among SMEs is very important. Nevertheless, despite these positive contributions to the economy and individuals, the development among SMEs in Malaysia is 
considered minimal and slow. This can be seen through the contribution of SMEs employment to total employment every year with average of $0.73 \%$ increment per year due to the increased in number of SMEs in Malaysia (HRDF, 2019).

According to Shepherd and Wiklund (2009) who reviewed studies of firms' growth, it was found that the owner's wellbeing is one of a vital aspect. It may vary from one firm to another, depending on the sector and the type of businesses. Nevertheless, they exhibit some common features, for instance, the desire to make profit and the ambition to impact in their niche market with their products. This shows that business owner's wellbeing inspires growth directly towards the operation of the firm. Even though research is slowly increasing in the subject of wellbeing and their role in the process of business growth (Bergmann, 2002) however, this argument is still scarce in the literature. As a result, a thorough understanding on SMEs business growth in Terengganu was very poor and the barriers remain persistent. This paper recognises that besides the vital need for expanding SMEs businesses, exploring wellbeing of business owner are critical in order to increase the potential of their business growth.

\section{Literature review}

\section{Definition of SMEs and importance of wellbeing}

In Malaysia, the most widely accepted definition for SMEs is by SME Corp. Malaysia which defines SMEs based on the number of employees and total sales revenue in a year (SME Corp. Malaysia, 2016) (Table 1). In addition, Malaysia SMEs are grouped into micro, small, or medium based on either the numbers of people a business employs or on the total sales or revenue generated by a business in a year (Hashim \& Abdullah, 2000).

Table 1: SME definitions (SMIDEC, 2004)

\begin{tabular}{lcccc}
\hline & \multicolumn{2}{c}{$\begin{array}{c}\text { Manufacturing, manufacturing related } \\
\text { services \& agro based }\end{array}$} & \multicolumn{2}{c}{$\begin{array}{c}\text { Services, primary agriculture \& } \\
\text { information and communication }\end{array}$} \\
\hline & Employees & $\begin{array}{c}\text { Sales turnover } \\
(\mathbf{R M})\end{array}$ & $\begin{array}{c}\text { Employees } \\
\text { Sales turnover } \\
(\mathbf{R M})\end{array}$ \\
Micro enterprises & $<5$ & $<250,000$ & $<5$ & $<200,000$ \\
Small enterprises & $5-50$ & $250,000-10 \mathrm{mil}$ & $5-19$ & $200,000-1 \mathrm{mil}$ \\
Medium enterprises & $51-150$ & $10 \mathrm{ml}-25 \mathrm{mil}$ & $20-50$ & 1 mil-5mil \\
\hline
\end{tabular}

SMEs plays an important role in job creation, the maintenance of entrepreneur's household livelihood, goods and services sources for larger organisations (Singh, Garg, \& Deshmukh, 2008) as well as preserving the culture for example, textile and craft sector. They are divided into two main sectors: Services sectors and Manufacturing sectors and these sectors are also divided into three categories: micro, small and medium size businesses. According to HRDF (2019), out of 98.5\% SMEs in Malaysia, $76.5 \%$ of them are micro sized, $21.2 \%$ are small sized and $2.3 \%$ are medium sized. Each sector are also divided into several more subsectors (Table 1).

Based on the Economic Census 2016 Food and Beverages (F\&B) subsector to have the second highest percentage in the services sector, which is $20.4 \%$. Similarly in the manufacturing sector, F\&B is also the second highest among all the subsectors which makes up $17.4 \%$ of the total percentage in that particular sector. Thus, this paper focuses on F\&B subsector as it is one 
of the most prominent sectors both in services and manufacturing sector. This subsector is in dire need of development and growth.

For the past decades, several studies (Wang, Watkins, Harris, \& Spicer, 2004; Littunen, 2000; Julien, 1998) highlighted that one of the normative criteria to evaluate the success of a business was indicated through its growth. In a recent study by Sarwoko and Frisdiantara (2016) showed three determinants of growth among SMEs; 1) the individual factors 2) organizational factors, and 3) environment factors. Le (2009) identified three models that are relevant to SMEs growth; 1) stochastic nature of firm growth, 2) human capital, 3) ability after entering into operation and adjust its behaviour. Apart from the first model which argued that company growth was based on pure chance and a result of collection of random shocks over time, this paper support the findings of the other two models discussed in Le (2009)'s paper. Particularly for the second model, it highlighted that SMEs are able to improve their company's growth through behaviour change which rooted from the understanding of their attitude that directly linked with their wellbeing.

\section{Theory of planned behaviour}

Theory of planned behaviour explain and predict why we do what we do and act the way we act. The theory assume that individuals usually behave in a respective manner as they calculate available information and implicitly or explicitly recognise the consequences of their actions (Ajzen, 2005). In addition, the theory predicates that individual's intention to execute (or not to execute) a behaviour is the predominant adjacent of that action. In an accordance with theory of planned behaviour, intentions are dictated by three basic determinants: attitudes toward act or behaviour, subjective norm and perceived behaviour control (Ajzen, 1987). Attitude toward behaviour are related to the individual's mind-set and feeling towards the behaviour. It is directly related to individual's believes that makes positive or negative contribution to their life. These attitude can be divided into affective attitude and instrumental attitude (Ajzen, 1987). Affective attitude is where the individual believes that the behaviour to be enjoyable or unenjoyable. Instrumental attitude refers to whether the behaviour believed to be beneficial or harmful. The second predictor of intention is subjective norms which refers to support given by significant others (Ajzen, 1987) which includes social network, cultural norms and group's believes. The last predictor is perceived behavioural control (Ajzen, 2005) which explain the extent to which an individual feels capable and has confident to execute the desired behaviour. This could be likened to the perception that an individual has the capabilities to overcome potential barriers and challenges. To conclude, when an individual perceived an activity as enjoyable with good benefits, where they have support and encouragement from others and ultimately feel that they have the ability to meet the demand of the task, they will form stronger intention and more likely to engage in the activity (Ajzen, 1991). As the construct of attitudes stems from the assumption that attitudes predict behaviour (Crano \& Prislin, 2008), this paper intend to focus on investigating business owner's attitude towards business growth.

\section{Wellbeing and business growth}

According to Davis (2019), wellbeing are defined as the experience of health, happiness and prosperity which includes having healthy mental state, great life satisfaction, understand life's meaning and purpose as well as high stress management competency. Even though the definition 
of wellbeing includes common reflection about wellbeing that associated with mental or psychological circumstances (Sfeatcu et al., 2014), investigating their wellbeing will enhance the understanding of one's action. Hence, exploring the wellbeing of entrepreneurs will enable in depth understanding on how SMEs endured business barriers (Wiklund, Nikolaev, Shir, Foo, \& Bradley, 2019)

Wellbeing is an essential part of entrepreneurship as it linked to 'people's ability to work, maintain positive relationships, and experience positive emotions' (Diener et al., 2010; Ryan \& Deci, 2000; Seligman, 2012). In addition, the central to the field of entrepreneurship are the correlation between individuals, actions and opportunities which expedite or hinder them from delivering value (Shepherd \& Patzelt, 2015). For instance, World Health Organization (2005) reported that there is increasing prove that support the correlation which is productivity at work.

Thus, it is vital to understand entrepreneur action, decision-making and motivation further (Shepherd \& Patzelt, 2015) by investigating their wellbeing in order to encourage business growth. Shir (2015) claims that it is crucial to recognise not only the impact of entrepreneurship on their mental health, but also the motivation behind their action by concentrating on wellbeing of entrepreneurs. In order to understand entrepreneurs' drives and motivation of decision making, knowing how, when and why their wellbeing were influenced plays a main role (Shir, 2015) especially among SMEs. Thus, in order to explore SMEs business owner's attitude which impede their business growth that directly linked with their wellbeing, this paper adopted indepth interview method.

\section{Theoretical framework}

This study integrates theoretical frameworks (Figure 1) of extant studies relevant to SMEs growth determinants. In this context, Sarwoko and Frisdiantara (2016) highlighted three growth determinants, i.e. organizational factors, individual factors and environment factors. As this study are focusing on individual factors, the theorem was extended using theory of planned behavior. 


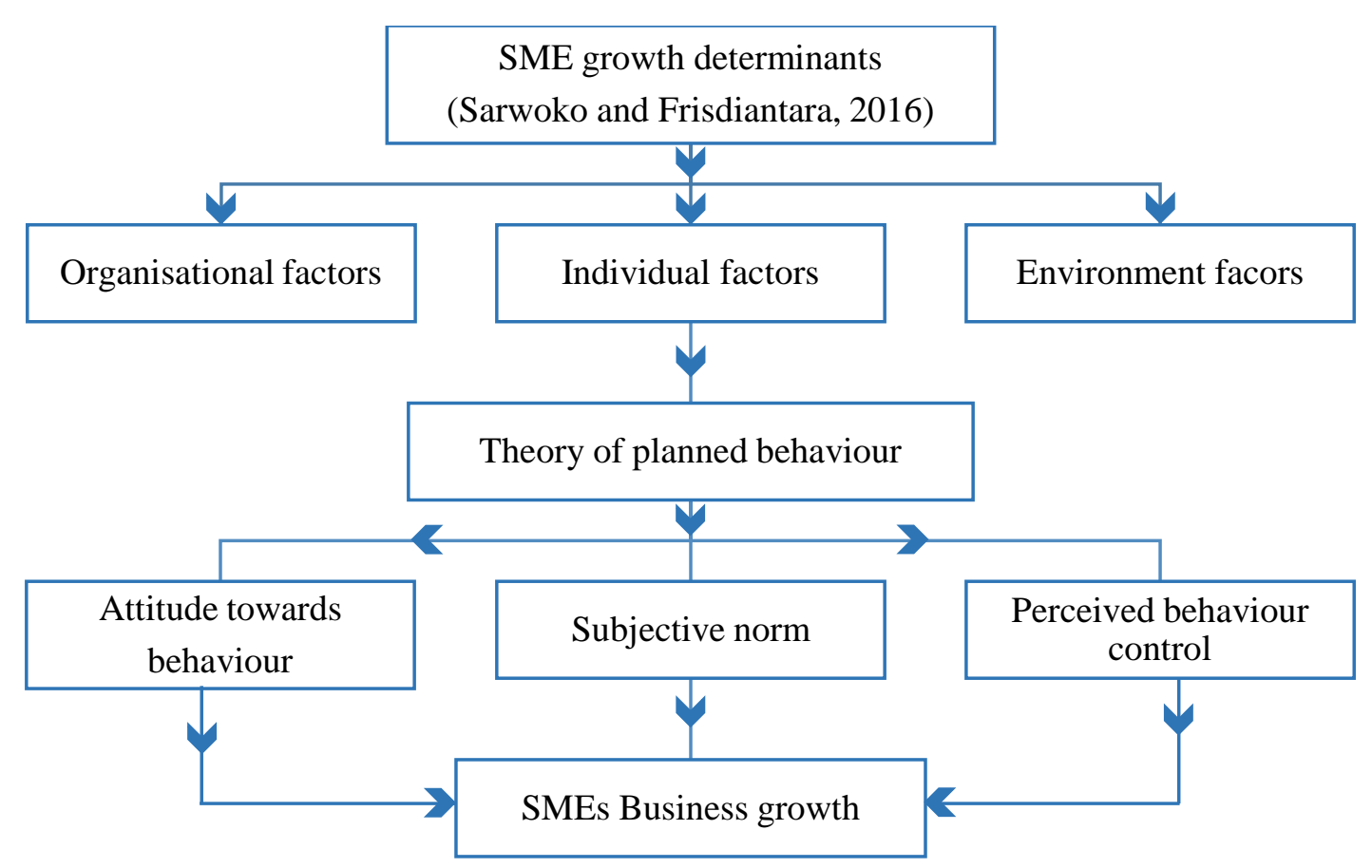

Figure 1: Theoretical framework

\section{Method and study area}

All of the data collected and presented in this paper is qualitative as it seeks to develop an indepth understanding of the relationship between wellbeing of business owners and business growth among SMEs in Terengganu. The aim of the selected method for this paper was to clarify SMEs business owner's attitude which impede their business growth. In order to obtain cohesive results and findings, an extensive evaluation of all factors and variables from reliable sources were carefully analysed. Before this section were discussed further, the definition of experts and business owners are as follows:

Table 3. Definition of respondents for this study

\begin{tabular}{ll}
\hline \multicolumn{1}{c}{ Respondents } & Definition \\
\hline Experts & SME related experts for example SME Corp CEO, PUNB \\
& managers, SIRIM CEO, DDEC managers and academicians \\
& involved with entrepreneurship programs. \\
Business owners & SME registered business owners with Terengganu Entrepreneur \\
& Development Foundation (TEDF) focusing on F\&B sector. \\
\hline
\end{tabular}

A semi-structured interview questions were then developed for an in-depth interview designed for 30 interviewees consisting of 15 experts from different fields of expertise and also the business owners of 15 companies. During these interviews, details of the finance, marketing and brand practices were drawn upon. The semi-structured nature ensured that the researcher could critically examine areas of interest, provide greater in-depth understanding of experts and obtain business owner's viewpoint of current business barrier within the organisation. As a result, a rich stream of data was created, enabling a broad and deep understanding of the current scenario encountered by the entrepreneur. 
The respondents' demographic profile were illustrated in Table 4 and Table 5. The reason of choosing both experts and business owners were to obtain a holistic view on business owner's wellbeing which was not bias towards any sides. For the experts' sources of insight process, purposive sampling was selected. A list of name of important key people in charge was provided by the TEDF. A total of 30 people were on the list and were carefully approached via email. However, only 10 of the list agreed to be interviewed considering the time frame given and the remaining 5 experts were selected using the snowball sampling sample when the first 10 respondents recommended them. As for business owners, a list of registered SMEs were obtained from TEDF. Fifteen out of forty company from F\&B sector that were contacted, agreed to be interviewed.

Data management and analysis were performed using ATLAS.ti program, which is a tool that allows the researcher to work closer with the transcribed data whilst also attempting not to stray from the transcribed data's original source. This allows the researcher to maintain the consistency of the transcribed data as it links the original interview recordings paragraph by paragraph. Thematic network analysis was then used as the main methodological aid in the analysis of the collected and transcribed data. Thematic analysis for this paper underwent three phases: pre analysis, keyword exploration, inference and interpretation. The first phase was where the raw transcribed data was analysed for the formulation of hypothesis. Next phase, words mention in the data were counted and a table were generated using the program. Most frequent words mentioned were notified and grouped thematically. Finally, the researcher were able to establish the results and linked it all together. 
Table 4. Experts' demographic profile

\begin{tabular}{|c|c|c|c|c|c|c|c|c|c|c|c|c|c|c|c|}
\hline \multirow{2}{*}{$\begin{array}{l}\text { Category } \\
\text { Agency }\end{array}$} & \multicolumn{9}{|c|}{ GLC } & \multicolumn{4}{|c|}{ Private } & \multicolumn{2}{|c|}{ University } \\
\hline & & TEDF & & $\begin{array}{l}\text { SME } \\
\text { Corp }\end{array}$ & MPC & PUNB & $\begin{array}{c}\text { SIRI } \\
\mathbf{M}\end{array}$ & & & & Col & Itant & & $\begin{array}{c}\text { UNIS } \\
\text { ZA }\end{array}$ & UMT \\
\hline Name & 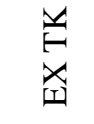 & 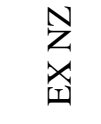 & $\begin{array}{l}\tilde{x} \\
\dot{x}\end{array}$ & $\sum_{\substack{x \\
\mid x}}$ & $\sum_{\substack{x \\
I}}$ & $\begin{array}{l}\grave{\partial} \\
\dot{x} \\
\text { I }\end{array}$ & 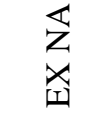 & 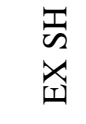 & $\begin{array}{l}\stackrel{a}{x} \\
\stackrel{x}{a}\end{array}$ & $\begin{array}{l}\text { 崖 } \\
\underset{I}{x}\end{array}$ & $\begin{array}{l}\tilde{y} \\
Z \\
x \\
\text { I }\end{array}$ & $\begin{array}{l}\vec{Z} \\
\underset{x}{x}\end{array}$ & $\begin{array}{l}D \\
\infty \\
x \\
\text { II }\end{array}$ & 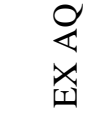 & $\begin{array}{l}\tilde{x} \\
\text { 壵 }\end{array}$ \\
\hline Gender & M & M & $\mathrm{F}$ & M & $\mathrm{F}$ & $\mathrm{M}$ & M & $\mathrm{F}$ & M & $\mathrm{M}$ & M & $\mathrm{M}$ & $\mathrm{M}$ & $\mathrm{F}$ & M \\
\hline Age & 57 & 36 & 34 & 44 & 42 & 41 & 40 & 38 & 43 & 29 & 34 & 45 & 47 & 31 & 39 \\
\hline Position & CEO & Mng. & Mng & CEO & Mng. & Mng. & CEO & Dsg. & CEO & Dsg. & Dsg. & Cons. & Cons. & Lect. & Lect. \\
\hline Experience (years) & 27 & 13 & 10 & 18 & 7 & 8 & 14 & 16 & 10 & 6 & 7 & 15 & 17 & 6 & 13 \\
\hline
\end{tabular}

Table 5. Entrepreneurs' demographic profile

\begin{tabular}{|c|c|c|c|c|c|c|c|c|c|c|c|c|c|c|c|}
\hline \multirow{2}{*}{$\begin{array}{l}\text { Recruit } \\
\text { method }\end{array}$} & \multicolumn{4}{|c|}{ TEDF List A } & \multicolumn{5}{|c|}{ TEDF List B } & \multicolumn{3}{|c|}{ Event } & \multicolumn{3}{|c|}{ Snowball } \\
\hline & $\begin{array}{l}\sum_{Z} \\
Z \\
Z\end{array}$ & $\underset{\text { Z }}{\sum_{I}}$ & $\begin{array}{l}\text { 这 } \\
\text { Z }\end{array}$ & $\begin{array}{l}\text { t } \\
Z \\
Z\end{array}$ & $\begin{array}{l}8 \\
Z \\
Z\end{array}$ & $\begin{array}{l}n \\
Z \\
Z \\
\text { Z }\end{array}$ & $\begin{array}{l}\stackrel{n}{Z} \\
\underset{I}{Z}\end{array}$ & 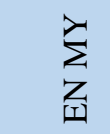 & $\begin{array}{l}\text { 岕 } \\
\underset{\text { Z }}{Z}\end{array}$ & $\begin{array}{l}\mathbb{I} \\
Z \\
Z\end{array}$ & $\sum_{Z}$ & $\begin{array}{l}\text { Z } \\
Z \\
Z\end{array}$ & $\begin{array}{l}\cong \\
\underset{I}{Z}\end{array}$ & $\begin{array}{l}Z_{Z} \\
Z \\
\text { II }\end{array}$ & $\begin{array}{l}N \\
Z \\
\text { ZI }\end{array}$ \\
\hline Gender & $\mathrm{F}$ & M & M & M & M & $\mathrm{F}$ & $\mathrm{F}$ & $\mathrm{F}$ & $\mathrm{M}$ & M & $\mathrm{F}$ & $\mathrm{M}$ & $\mathrm{F}$ & $\mathrm{F}$ & $\mathrm{M}$ \\
\hline Age & 52 & 45 & 36 & 34 & 29 & 25 & 30 & 34 & 28 & 46 & 40 & 54 & 38 & 36 & 57 \\
\hline $\begin{array}{l}\text { Level of } \\
\text { education }\end{array}$ & Deg. & SPM & Deg. & Dip. & Dip. & Dip. & Deg. & Dip. & Dip. & Deg. & SPM & Deg. & MSc. & Deg. & SPM \\
\hline Business & $\begin{array}{l}\text { Food } \\
\text { paste }\end{array}$ & Drinks & Snack & Noodle & Rice & $\begin{array}{l}\text { Trad. } \\
\text { food }\end{array}$ & $\begin{array}{l}\text { Trad. } \\
\text { food }\end{array}$ & $\begin{array}{l}\text { Hot } \\
\text { food }\end{array}$ & $\begin{array}{l}\text { Hot } \\
\text { food }\end{array}$ & Snack & Snack & Drinks & $\begin{array}{l}\text { Hot } \\
\text { food }\end{array}$ & Snack & $\begin{array}{l}\text { Hot } \\
\text { food }\end{array}$ \\
\hline Employee & 50 & 20 & 10 & 25 & 28 & 6 & 8 & 7 & 15 & 46 & 7 & 35 & 5 & 10 & 7 \\
\hline Inherit & No & No & No & Yes & Yes & Yes & Yes & No & Yes & No & No & No & No & No & No \\
\hline
\end{tabular}


The location for field research was Terengganu. According to Economic Census (2011) this region had the strongest growth potentials as only 3.5\% SMEs in Malaysia are from Terengganu. SMEs also represent a significant revenue stream for Terengganu, contributing $49.4 \%$ to state GDP (TETU, 2018). The highest contributing sector is services sector, $88.3 \%$ with a total of 19,882 SMEs (SME Corp. Malaysia, 2016). Out of all subsectors in the service sector, $71 \%$ of them are $F \& B$ sector and it is deemed to make the highest contributions. Several product categories were identified as having strong market potential, including ready-to-eat snacks, ready-to-eat hot food and frozen food. Thus, with a high density of $88 \%$ micro sized SMEs in Terengganu (TETU, 2018), this study chose this region as a field research with a focus on F\&B subsector.

\section{Results and discussion}

The objective of this paper is to explore SMEs business owner's attitude that impede their business growth. Positive attitude among business owner evidently played pivotal role in business growth. To support this, Expert TK claimed that:

\section{It is crucial that SMEs in Terengganu have to change their mind set and attitude towards business growth.}

The most common trait found among successful business owners, regardless of the size of their business is constantly growing their business. 'What is next' is a critical factor in a longterm business planning growth. This positive attitude attracted success for so many businesses. In smaller firms, the business founder's attitudes determine how the business develops (Fillis, Johansson, \& Wagner, 2006). Therefore, an 'I want more' attitude is highly demanded in operating business. Identifying their common attitudes notably allowed further understanding, which led to a more comprehensive development of their business growth. To avoid a bias in findings on attitudes among SMEs, interviews were also include business owners and SMEs related experts as interviewees. The data showed that there were six common attitude found among SMEs in Terengganu through in-depth interviews.

\section{a. Complacency}

Complacency is defined as an attitude of being satisfied with what they already have and feeling comfortable with their current state of doing business. Complacency was found mainly among micro SMEs in Terengganu. Expert IK further supported this finding when he was questioned regarding the current scenario in Terengganu. He suggested:

SMEs tend to have an 'I had enough' attitude. They did not set their mind to go further and have a long-term goal and aim. 'If I spend more on logo, I will not have enough money later'.

Similarly, the view was also supported by Expert NA who stated that most entrepreneurs does possess the said attitude. He also added that this was commonly found among conventional entrepreneurs, which makes it more complex because they were far more resistant to new 
systems and change compared to young entrepreneurs. Furthermore, Expert R, who is the CEO in DDEC, shared his ideas regarding the complacent attitude among local SMEs in Terengganu:

I've approached a bakery called 'ROTI ABDULLAH'. They have their own packaging, but for them to go further they have to be at par with Gardenia regarding packaging. So when I approached the owner, and said, 'I want to help you re-design your packaging and have a suitable fund under MARA. Surprisingly, he answered 'what I have now is enough for me'.

Based on Expert R's experience, it can be seen clearly how easily satisfied local SMEs were with their current business and sales regardless of the fact that they had been doing the same thing for the past ten years. Approximately half of the interviewees reported that the most of entrepreneurs in Terengganu have poor self-confidence due to their low education level. Similar to Arthur-Aidoo, Aigbavboa and Thwala (2016) the low level of educational qualification of owners had established attitudes that compel them to exhibit non-standardised managerial practices which resulted in poor human relations among employees thereby affecting their business' growth. To support this, Entrepreneur N mentioned:

One of the reasons why local SMEs fail to grow their business is because their academic level is low.

Entrepreneur NZ adopted a broader perspective regarding this matter, which he claimed that the complacency attitude might have resulted from the government itself. He added that the government provided too many facilities and indirectly pampers business owner with all the leverages. As a result, they feel easily satisfied with what they received. This could lead to the emergence of an attitude of being reliant on government's support.

\section{b. Reliance}

Along with the complacency attitude, there was an increasing concern over the high reliance on the government. In a similar way to SMEs in the UK who rely overwhelmingly on banks for their funding (Freeman, 2013), SMEs in Terengganu were also found to heavily rely on government supports and grants.

According to SME Corp. Malaysia (2015), in 2014, 124 SME training programs were organised by five agencies (i.e. MARA, TEDF, SME Corp, PUNB and MATRADE) in Terengganu, alone (Table 7). Other than that, they had to rely on other resources in operating their business owing to the scarcity of financial resources and limited R\&D capability. Expert TK stated that:

SMEs dependant attitude towards governmental funds was a very common scenario I faced based on my experience. Being independent were hardly a common attitude among local SMEs. They tend to wait for help rather than working for it. 
Table 7. Training programs in Terengganu in 2014

\begin{tabular}{lccccc}
\hline \multicolumn{1}{c}{ Agencies } & MARA & TEDF & SME Corp & PUNB & MATRADE \\
\hline $\begin{array}{l}\text { No. of training } \\
\text { programs }\end{array}$ & 43 & 45 & 7 & 25 & 4 \\
No. of participants & 2838 & 3566 & 518 & 1033 & 234 \\
\hline
\end{tabular}

Expert TK also added that SMEs in Terengganu heavily relied on the governments when they need financial grants or assistance. Based on the data, this attitude occurrence was also supported by Expert $\mathrm{S}$, when she pointed out that the quantity of help provided by the Terengganu state government is higher compared to other states for example, Kelantan. Experts in this study asserted that even though it has a similar level of development to Terengganu, the amount of grants provided by their state government is considerably lower. Expert $\mathrm{S}$ also admitted that local SMEs have become weaker as they highly dependent on the government. This scenario portrayed their current attitude, which may result in delaying the effort to operate and grow their businesses. Business owner tend to put off their work and opt for government funding instead rather than putting the effort to gain the financial resources themselves.

\section{c. Expectations}

In most cases, business owner have high expectations from the government and bigger companies to assist their business from which the attitude of expectation emerged. They expected everything to be free of charge and easily accessible. It is impossible to attend to their demands as they simply refused to work more to get better results. Expert TK shared his experience with SMEs:

They even said to me that if the government does not give or assist with money and funding, they refuse to go to the seminar.

Expert S shared that her experience supported Expert TK. She pointed out that:

Most of the local SMEs do not want to join organised talks and training by the organisations, especially the paid ones. They were reluctant to spend money on acquiring knowledge.

Based on Expert S and Expert TK claims, it can be concluded that SMEs were reluctant to join paid training programs as they insisted that those investment will not bring them any profit as they failed to see the long-term benefit of it. Their limited viewpoint halted their understanding of the cycle of business as a whole entity. This explains their tendency to undervalue other people's efforts and demand that everything is served to them free of charge. Furthermore, they were unaware of the process of acquiring knowledge and skills in order to attain a good quality outcome. For instance, the time spent for research and development purposes was commonly undervalued and underestimated by business owner.

With the emergence of the attitude of expectation, the importance of knowledge seems to be highly relevant for this paper because they tend to wait for help rather than to work for it or finding other solutions for the barriers that hindered their growth. This was supported by Business Owner AZ: 
They are also afraid of change and of growing their business. They frequently said it is due to money, majority of them wait for government grants. If they have this kind of attitude, they are mostly only 'waiting' for help.

Business Owner AS was recognised as one of the Top 10 most successful SMEs in Terengganu, also added that the implication of this particular attitude of expectation were reluctance to commit to extra work and tendency to adopt an 'easy-way' approach rather than putting in more effort. This expectation attitude is totally the opposite of her own attitude, which was pro-active, positive and risk taking. As this attitude was investigated further, data found that their behaviour was due to the insecurity of taking risks as opposed to how a successful business owner would act. This emergence of data was found when Business Owner AZ suggested that:

When SMEs said they do not have enough money, they don't want to make a loan to solve that problem. This is because they are afraid of taking a risk. They are still waiting for grants from government, which are very limited.

\section{d. Inculpate}

A correlation was found between the reliance and expectation attitudes which resulted in the inculpate attitude. The inculpate attitude is defined as an attitude of business owner whom opt to blame others rather than themselves. This view was supported by Expert TK:

SMEs tend to blame the government even though they're the ones who ignore and do not even look for information on how to better their business.

Expert AZ supported that ultimately business owner would come up with an affirmation that the agencies/government did not help them. Expert TK believed that everybody is blaming each other: business owner blame agencies for not telling them the availability of the grants and the agencies blame business owner for not inquiring about the information. The claims will result in an endless circle of arguments where nobody wants to own the responsibility. Business owner can start by dismissing the inculpate attitude and changing their perception towards the government. The government's support exist to leverage their businesses hence this will be the starting point for them to seek for help.

\section{e. Unmotivated}

The data shows that small business productivity and survival are greatly dependent on the motivation of the individuals involved. However, SMEs in Terengganu were found to have poor level of motivation. Lack of motivation or negative attitude, which constrain creativity, risktaking and adequate returns on investment were inimical to innovative behaviour by smaller enterprises. The results obtained from the preliminary analysis of the motivational level among business owner in Terengganu were lower compared to those in Johor. This view was supported by Business Owner AZ who pointed out his experience:

For example, in my experience, I already have an offer from Johor to supply me 4 tons of cucumber. It shows their open-mindedness and far-sightedness. 
Unfortunately here in Terengganu, it took me 2 years to convince farmers to sign the contract farming with me to supply cucumbers.

Parallel to the attitude of expectation, an unmotivated attitude emerged due to poor level of understanding of their business. Expert AZ also added that majority of business owner were unsure of the needs of their businesses therefore, they fail to plan any action plan. This attitude was directly related to their complacency which resulted in them being unmotivated.

\section{f. Incurious}

The most striking result to emerge from the data was that in addition to the unmotivated attitude was the emergence of an incurious attitude where they refused to learn new things to improve their businesses. The incurious attitude affected both business owner and experts. Business owner were clueless about the available support for their business and experts were unaware of business owner's barriers. For instance, business owner fail to solve the simplest barrier affecting their business growth due to this incurious attitude. Similarly, Expert SH suggested that:

Not asking and lack of reading also make things worse and this scenario prolong until forever. Even though it sounds lame and tiring to do all those planning, BUT for you to grow big, you need to put on paper.

Against this backdrop, there was a need to create the conditions that enables the improvement of these six common attitudes to be implemented and shared more broadly across business owner and experts. In conclusion, by clarifying the common attitude was insufficient, hence this paper investigated further the motives behind their attitude. Entrepreneur KH was asked whether other entrepreneurs were aware of their problems. He affirmed that some of them were aware, and some of them were not. However, he added that for those who are aware that they lack in knowledge, they do not know what to do next, and have no action plan. Unfortunately, they refused to ask experts, as they were afraid to be labelled as stupid, so they make their own decisions without experts' recommendations. In addition, a small number of those interviewed also suggested that entrepreneurs tend to give up easily because they underestimate their own ability. To support this, Entrepreneur KH stated:

Some entrepreneurs also have the attitude of easily giving up if the market doesn't want their product. They don't have the confidence in their product to fight for it. They also didn't even bother finding out the market's demand to improve their product.

In response to the question: 'why do SMEs fail to grow their business?' a range of responses were elicited. The majority of those who responded to this question felt that it is mainly due to the day-to-day basis activity in running their business. To support this, Expert SH stated that the reason behind entrepreneurs' behaviour was:

Because they are too tired with the day-to-day production and don't have enough time to do all those planning. 
This study suggested that factors affecting the inclination of an owner to report growth might include their daily routine. The researcher had considered this in two ways: in-depth interviews among experts and entrepreneurs as a measure of the general business environment, and the shadowing of Entrepreneur MM as a measure of validating the data. The researcher was unable to conduct the study on a larger scale due to time constraints. However, the day-to-day basis among SMEs appeared to substantially affect their growth in business. According to Davidsson, Achtenhagen, and Naldi (2005) the attitude and motivation of founders/CEOs could change dramatically due to events in their business or private lives. The schedule of their daily lives was found to be so packed and consist of repeated routine for the whole week. This might resulted in excessive fatigue experienced by the entrepreneur which became one of the main reasons they could not cope with the technical and paperwork matters concerning their business.

\section{Limitation of Study}

The important limitation lies in the results from this particular study of SME business growth among the $F \& B$ sector might be significantly different compared to the business growth of other sectors - this particular context may have influenced the findings. Moreover, the results are narrowed to a single geographical location; data is collected only in Terengganu, Malaysia. As the results were limited only to Terengganu context, they might not be applicable to other SMEs in other states in Malaysia. Therefore, it is recommended that future studies need to be replicated and extended to other different contexts and would benefit from researching a wider geographical scope to other states in Malaysia.

\section{Conclusion}

Despite having to operate with limited resources, SMEs are the mainstay of the majority of national economies. Based on analysis, understanding business owner's attitude linked directly with promoting their wellbeing. Strong evidence was found that overcoming attitudinal limitations is one of the keys to improve SMEs business growth. This paper suggested three recommendation for SMEs in order to improve their wellbeing. First, business owner need to establish positive networking among SMEs. In addition, business owners should develop a strong relationship between other SMEs in their sector as well as those in other sectors by broaden and seize their networking oppportunities. The results of the paper suggested SMEs do benefit from networking by having several options of raw material suppliers or a better branding consultant. Second, business owner have to encourage and develop self-motivation as the result from the interview indicated that business owners' self-motivation and productivity increased under a positive and social connectedness via networking. This is attained due to business owner feel more involved and responsible, have positive perceptions towards business growth and actively strive to develop their business. Finally, the owner's attitude and vision should be positive and well balanced between business and personal life. In order to achieve that, working on a day-to-day basis needs to be abolished and replaced with scheduled working hours. They need to give themselves at least a day off each week. Therefore, they can have a good rest and it can also boost their productivity and emotions. 


\section{References}

Ajzen, I. (1987). Attitudes, traits and actions: dispositional prediction of behaviour in social pshychology. In Advances in Experimental Social Psychology (Vol. 20, pp. 1-63). Elsevier Science \& Technology.

Ajzen, I. (1991). The Theory of Planned Behavior. Organizational Behavior and Human Decision Processes, 50, 179-211. https://doi.org/10.1080/10410236.2018.1493416

Ajzen, I. (2005). Attitudes, Personality and Behavior. Berkshire, England: Open University Press.

Arthur-Aidoo, B. M., Aigbavboa, C. O., \& Thwala, W. D. (2016). Attitudes of Owners which Impedes Firm's Growth: A Case of Small and Medium-sized Construction Firms in Ghana. Procedia Engineering, 164(June 2017), 230-234. https://doi.org/10.1016/j.proeng. 2016.11.614

Bergmann, H. (2002). Cultural aspects of entrepreneurship.

Crano, W. D., \& Prislin, R. (2008). Attitudes and attitude change. New York: Psychology Press.

Davidsson, P., Achtenhagen, L., \& Naldi, L. (2005). Research on small firm growth: A review. European Institute of Small Business, 1-27. https://doi.org/10.1007/978-0-387-32313-8_13

Davis, T. (2019). What is well-being? Definition, types, and well-being skills. Retrieved from https://www.psychologytoday.com/intl/blog/click-here-happiness/201901/what-is-wellbeing-definition-types-and-well-being-skills

Department of Statistics Malaysia. (2011). Economic Census 2011: Profile of Small and Medium Enterprises.

Diener, E., Wirtz, D., Tov, W., Kim-Prieto, C., Choi, D. won, Oishi, S., \& Biswas-Diener, R. (2010). New well-being measures: Short scales to assess flourishing and positive and negative feelings. Social Indicators Research, 97(2), 143-156. https://doi.org/10.1007/ s11205-009-9493-y

Fillis, I., Johansson, U., \& Wagner, B. (2006). A qualitative investigation of smaller firm ebusiness development. https://doi.org/10.1108/14626000410551609

Freeman, A. (2013). “ Challenging myths about the funding of small businesses ...” Finance for Growth. London: Demos finance.

Hannu Littunen. (2000). Entrepreneurship and the characteristics of the entrepreneurial personality. International Journal of Entrepreneurial Behaviour \& Research, 6(6), 295310. https://doi.org/https://doi.org/10.1108/13552550010362741

Hashim, M. K., \& Abdullah, M. S. (2000). Developing small and medium-sized enterprises (SMEs) taxonomy in Malaysia.

HRDF. (2019). Human Resource Development Fund (HRDF) human capital report.

Julien, P.-A. (1998). The State of the Art in Small Business and Entrepreneurship. In The State of the Art in Small Business and Entrepreneurship. https://doi.org/10.4324/9780429429545

Le, V. (2009). Small firm growth theory and models: A review (No. 22nd SEAANZ Annual Conference).

Ryan, R. M., \& Deci, E. L. (2000). Self-determination theory. Development of SelfDetermination Through the Life-Course, 55(1), 47-54. https://doi.org/10.1007/978-94-0241042-6_4

Sarwoko, E., \& Frisdiantara, C. (2016). Growth Determinants of Small Medium Enterprises (SMEs). Universal Journal of Management, 4(1), 36-41. https://doi.org/10.13189/ ujm.2016.040105 
Seligman, M. (2012). Flourish: A visionary new understanding of happiness and well-being. In William Heinemann Australia. https://doi.org/10.1017/CBO9781107415324.004

Sfeatcu, R., Cernuşcă-Miţariu, M., Ionescu, C., Roman, M., Cernuşcă-Miţariu, S., Coldea, L., ... Burcea, C. C. (2014). The concept of wellbeing in relation to health and quality of life. European Journal of Science and Theology, 10(4), 123-128.

Shepherd, D. A., \& Patzelt, H. (2015). The "heart" of entrepreneurship: The impact of entrepreneurial action on health and health on entrepreneurial action. Journal of Business Venturing Insights, 4, 22-29. https://doi.org/10.1016/j.jbvi.2015.08.001

Shepherd, D., \& Wiklund, J. (2009). Are We Comparing ApplesWith Apples or ApplesWith Oranges? Appropriateness of Knowledge Accumulation Across Growth Studies. 105-124.

Shir, N. (2015). Entrepreneurial well-being: The payoff structure of business creation. https://doi.org/10.13140/RG.2.2.32847.74407

Singh, R. K., Garg, S. K., \& Deshmukh, S. G. (2008). Strategy development by SMEs for competitiveness: A review. Benchmarking: An International Journal, 15(5), 525-547. https://doi.org/10.1108/14635770810903132

SME Corp. Malaysia. (2015). SME Annual Report 2015/2016. In SME Corp. Malaysia. Retrieved from http://www.smecorp.gov.my/vn2/node/1856

SME Corp. Malaysia. (2016). SME ANNUAL REPORT 2015/16.

SME Corporation Malaysia. (2018). Key Milestones Towards Transformation. 1-108.

SMIDEC. (2004). SME performance 2003. Kuala Lumpur, Malaysia.

Terengganu Economic Transformation Unit (TETU). (2017). Terengganu's Economic Transformation Programme: The way forward.

Wang, Y., Watkins, D., Harris, N., \& Spicer, K. (2004). The relationship between succession issues and business performance: Evidence from UK family SMEs. International Journal of Entrepreneurial Behaviour \& Research, 10(February), 59-84. https://doi.org/10.1108/ 13552550410521380

Wiklund, J., Nikolaev, B., Shir, N., Foo, M. Der, \& Bradley, S. (2019). Entrepreneurship and well-being: Past, present, and future. Journal of Business Venturing, 34(4), 579-588. https://doi.org/10.1016/j.jbusvent.2019.01.002

World Health Organization. (2005). Promoting mental health nursing research in low and middle income countries. In International Nursing Review (Vol. 51). https://doi.org/10.1111/ j.1466-7657.2004.00268.x 